\title{
ЗАКОНОМЕРНОСТИ ЛОКАЛИЗАЦИИ И ЭВОЛЮЦИЯ БЛАГОРОДНОМЕТАЛЛЬНОГО РУДООБРАЗОВАНИЯ ВЕДЛОЗЕРСКО- СЕГОЗЕРСКОГО ЗЕЛЕНОКАМЕННОГО ПОЯСА (КАРЕЛИЯ)
}

Кулешевич Л.В., Лавров О.Б., Дмитриева А.В.

Институт геологии КарНЦ РАН, Петрозаводск, kuleshev@krc.karelia.ru

Ведлозерско-Сегозерский зеленокаменный пояс (ЗП) формировался на западной окраине Водлозерского блока в интервале времени 3.05-2.85 млрд. лет в разных геодинамических обстановках: островодужной, задугового бассейна и окраинно-континентальной. Окраинноконтинентальные вулканогенно-осадочные комплексы сопровождаются колчеданным и колчеданно-полиметаллическим оруденением. Мезоархейский орогенный этап завершился 2.86-2.85 млрд. лет кислым интрузивным магматизмом, складчатыми деформациями и метаморфизмом зеленосланцевой-эпидот-амфиболитовой фации. Вмещающие толщи прорываются известковощелочными диорит-плагиогранитными массивами (2.85 млрд. л.), дайками в их ореоле, небольшими порфировыми интрузиями (Талпус). С кварцевыми штокверками, прожилковыми линейными зонами и зонами рассланцевания в экзоконтактах этих массивов связано образование небольших $\mathrm{Au}-\mathrm{S}, \mathrm{Au}-\mathrm{S}-\mathrm{As}-$ рудопроявлений, перспективных на золото. Наращивание земной коры в интервале времени 2.9-3.0 млрд. лет и более древний этап гранитообразования (Чебинский массив и другие ТТГ-комплексы западного и С3 обрамления Водлозерского блока) не сопровождаются сульфидной рудной минерализацией.

Формирование ЗП в западном обрамлении Водлозерского блока и магматическая активность позднего этапа (2.74-2.65 млрд. л.) завершается заложением пулл-апарт структур и внедрением умереннощелочных массивов санукитоидной серии (2.74 млрд. л.) и калиевыми гранитами (2.7-2.68 млрд. л.) вдоль западной окраины Водлозерского блока. Как показывает анализ, проведенный для Карелии, и данные по металлогенической специализации массивов санукитоидной серии на других докембрийских щитах, умереннощелочные гранитоидные массивы могут рассматриваться как рудопродуцирующие и перспективные на золото [1].

В соответствии с выделяемыми геодинамическими обстановками и благоприятными типами пород, золоторудные месторождения/проявления орогенного этапа в архейских зеленокаменных толщах Эльмусской и Хаутавааро-Ведлозерской площадей представлены разными типами руд: 1 - золото-содержащими колчеданными; 2 - Au-S, Au-S-As жильными, связанными с известковощелочными гранитными массивами, дайками и малыми порфировыми телами (2.85 млрд. л.); 3 - Au-Cu-Мо-порфировые и Au-редкометалльные проявления, сопровождающие граниты повышенной щелочности (2.74 млрд. л); 4 - Au-S, Au-S-As, Au-редкометалльными в позднеархейских шир-зонах.

Наложение палеопротерозойских и свекофеннских рудных процессов на архейские зеленокаменные породы в западном обрамлении Ведлозерско-Сегозерского ЗП и формирование месторождений и рудопроявлений в них соответствующего возраста не подтверждается и требует доказательств.

Мезоархейская металлогеническая эпоха С вулканизмом кислого и среднего состава калаярвинской, кивилампинской и бергаульской свит связано наиболее интенсивное колчеданное рудообразование в интервале времени 2.88-2.85 млрд. лет. К этим свитам приурочены месторождения/рудопроявления колчеданных и колчеданно-полиметаллических руд в мезоархейских ЗП в обрамлении Водлозерского блока (объединенные в колчеданный пояс Карелии). В колчеданно-полиметаллических рудах Хаутаваарского месторождения, кроме основных сульфидов (пирита и пирротина), присутствуют сфалерит, халькопирит (Zn 17.02 \%, Cu 1 \%, S 38-44 \%) [9], $\mathrm{Au}$ до 1-5.5 г/т. На Нялмозерском и Ведлозерском рудопроявлениях содержания Аu достигает 3-3.9 г/т. На Улялегском колчеданном рудопроявлении содержание $\mathrm{Au}-0.01-0.1$ г/т. В южной части площади в колчеданно-полиметаллических рудах (проявления Нялмозерское, Койноваара, Кайназъярви, Саваярвинское) повышается содержание $\mathrm{Pb}$ (возможно влияние гранитов рапакиви). 
В Койкарской структуре колчеданные руды пиритового типа содержат низкие концентрации микропримесей. На Эльмусской площади на проявлении Талпус колчеданные залежи образуют согласные с вмещающими сланцами бергаульской свиты лопия маломощные (7-13 м) линзующиеся тела субмеридионального простирания (C-93, С-303, 302). Текстура колчеданных руд массивная, вкрапленно-полосчатая. Руды содержат пирит (70-80 \%), арсенопирит (1-5 \%), в небольшом количестве пирротин, халькопирит, сфалерит и золото. Арсенопиритовая минерализация в колчеданах, как предполагается, может быть наложенной. Содержания золота в рудах достигают 2-5 г/т.

Мезоархейский гранитоидный магматизм (комплексы Шуйский, Орехозерский, Карташинский, массив Талпус) завершает ранний орогенный этап формирования западного обрамления Водлозерского блока (2.86-2.85 млрд. л.). С «внутриструктурными» массивами, особенно с малыми телами и дайками, а также зонами рассланцевания в их экзоконтактах связана золотосульфоарсенидная минерализация, установленная на участках Талпус, Гавшламноя, Эльмус, Столбовая гора, золото-полиметаллическая минерализация (Восточное Орехозеро) $[3,5,10]$. Проявление Талпус-«гранитный» приурочено к кварцевому штокверку в небольшом внутриструктурном мас-

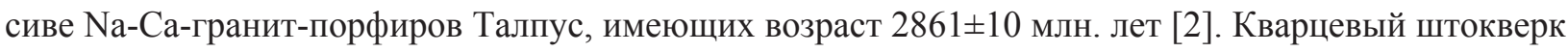
сформирован системой С3 и СВ жил. К зальбандам кварцевых жил приурочен тонкоигольчатый арсенопирит (5-7 \%), с ним ассоциируют пирит, галенит, реже встречаются сфалерит и халькопирит. На удалении от центральной части штокверка развиты сульфиды - пирит, халькопирит, сфалерит, сульфосоли (тетраэдрит-теннантит и $\mathrm{Pb}-\mathrm{Ag}-\mathrm{Sb}-\mathrm{S}$ ряда). Тонкое золото (и электрум в поздних ассоциациях) в штокверковой зоне представлено в срастании с пиритом [5].

К субмеридиональным шир-зонам центральной части Эльмусской зеленокаменной структуры, к экзоконтактам крупных ТТГ-массивов, либо к штокверковым зонам над невскрытыми массивами, приурочены золото-сульфоарсенидные проявления. Оруденение проявления Талпус«арсенопиритовый» (C-303) приурочено к кварц-альбит-анкерит-хлоритовым метасоматитам, формирующимся по рассланцованным кислым туфогенно-осадочным породам в субмеридиональной шир-зоне. Руды проявления Талпус-«арсенопиритовый» вкрапленные, вкрапленно-прожилковые, содержат арсенопирит (7-15 \%), пирротин (1-3 \%), редкие сульфиды полиметаллов и золото, секутся пирит-кварц-карбонатными прожилками (пирита $\sim 1-5 \%$ ). Арсенопирит срастается с пирротином и сульфидами полиметаллов, в нем встречаются микронные включения золота, реже электрум. Содержание $\mathrm{Au}$ в рудах достигает 20.8 г/т.

В западном обрамлении Карташинского и Орехозерского гранитоидных массивов к зоне контакта приурочены рассланцованные вмещающие толщи и система порфировых даек. Зоны рассланцевания сопровождаются вкрапленно-прожилковой Au-S-As- или Au-S-минерализацией (проявления Южное и Восточное Орехозеро, Гавшламноя). Au-S-As-минерализация проявления Гавшламноя содержит Au 0.05-0.5 г/т, As 4.13 \%; Cu в ppm - 280, Sb 59, Ni 30-152, Pb 9.5, W 63, Y 46. $\mathrm{Au}-\mathrm{S}$-проявление Восточное Орехозеро характеризуется повышенными концентрациями $\mathrm{Cu}(0.62-1 \%)$, $\mathrm{Bi}, \mathrm{Au}$ (от 3.22 - до 18 г/т). К кварцевому штокверку в кислых вулканогенно-осадочных толщах над невскрытой интрузией приурочена арсенопиритовая минерализация Эльмусского проявления. Содержание As во вкрапленно-прожилковых рудах достигает $10 \%$, Ag до 11.4 г/т, $\mathrm{Cu}$ до 0.7 \%, $\mathrm{Pb}$ до $0.2 \%, \mathrm{Zn}$ до $1 \%$, W до 0.06-0.1 \%, Аu в среднем составляет 4.2 г/т (до 15 г/т, по данным КГЭ).

К субмеридиональным позднеархейским зонам сдвиговых деформаций относится золотопиритовая минерализация месторождения Педролампи с высокопробным золотом [3]. Золотосульфидная минерализация приурочена к ССВ шир-зоне в сланцах по основным туфам. Рудокласты и обломки жил встречаются в перекрывающих осадках и грубообломочных породах. Возможно, что формирование этого небольшого месторождения произошло в интервале 2.72 млрд. л., так как золото встречается в перекрывающих осадках, относимых к пулл-апарт структурам. В зоне окисления на участках Педролампи и Южка встречается крупное в пиритах (Педролампи) и тонкодисперсное (Южка) золото, переотложенное в лимонитовой массе. 
Неоархейская металлогеническая эпоха в обрамлении Водлозерского блока связана с внедрением умереннощелочных санукитоидных комплексов - преимущественно массивов граносиенитов-монцогранитов. С граносиенитами Хаутаваарского массива (2.74 млрд. л.) связано золоторудное проявление Центральное Хаутаваарское (участки Северный и Центральный). Оруденение приурочено к северо-восточной части массива, к С3 линейной штокверковой зоне, прослеженной на расстояние около 1 км. Система жил в штокверке имеет С3 и СВ простирание. Наиболее высокие содержания золота связаны с пирит-кварцевыми жилами и зонами рассланцевания и изменения участка Центральный. Основная жила на этом участке имеет $\mathrm{CB}$ простирание $\left(70^{\circ}\right)$ и крутое падение $\left(\mathrm{C} 385^{\circ}\right)$. Кроме нее вскрыта серия и более мелких С3 прожилков на участке Северный. Содержание Au в зальбандах основной жилы достигает 6-28 г/т, в более мелких прожилках - 1-5.61 г/т. Рудная минерализация сопровождается аномальными концентрациями $\mathrm{Mo}, \mathrm{Cu}, \mathrm{Pb}, \mathrm{Te}, \mathrm{Bi}, \mathrm{Ag}$ в относительно слабо измененных граносиенитах. Для проявления Центральное Хаутаваарское ресурсы категории $\mathrm{P}_{1}$ составляют 2.015 т (при средних содержаниях Аu 2.83 г/т на участке Северном и 7.05 г/т на участке Центральном, по данным ООО «Онего-Золото»). На участке Центральном пиритовая минерализация в зальбандах жил сопровождается золотом, молибденитом, встречаются галенит, халькопирит и более редкие $\mathrm{Bi}-\mathrm{Te}-\mathrm{Pb}-\mathrm{S}$ фазы - сульфосоли и висмутотеллуриды [4]. На участке Северном рудная минерализация в рассланцованных и измененных граносиенитах и зальбандах прожилков представлена молибденитом, пиритом, золотом, встречаются пирротин, халькопирит, реже единичные галенит, цумоит, гессит, шеелит. Соотношение $\mathrm{Cu} / \mathrm{Mo}$ в штокверке колеблется от 0.1 до 67, в рудах с молибденитом - наиболее низкое и составляет 0.1-1, что характерно для Mo-S

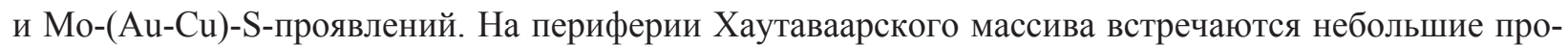
явления полиметаллов, в которых также установлены несколько повышенные концентрации золота. Между массивами Хаутаваарским и Коруд в C3 шир-зоне выявлено рудопроявление Au-S-As и Au-Bi рудопроявление Раялампи [6].

Золото-сульфоарсенидное месторождение Новые Пески расположено в небольшой архейской зеленокаменной структуре в юго-восточной части Хаутавааро-Ведлозерской площади. Au-SAs-минерализация небольшого месторождения Новые Пески (Au 2.59 г/т) в юго-восточной части Карелии представлена арсенопиритом, леллингитом, золотом ( 7 \% Ag), реже сульфидами железа и меди и акцессорными минералами - галенитом, мальдонитом, висмутом, шеелитом [7]. Ассоциация представленная арсенопиритом, леллингитом, золотом с пирротином, либо пиритом, формируется в разных условиях в зависимости от соотношения As и S. В большинстве докембрийских высокотемпературных Au-S-As месторождений в условиях дефицита серы формируются руды с золотосодержащим леллингитом. На стадии ретроградного метаморфизма, в условиях привноса серы в зонах деформаций, последовательно образуются ассоциации арсенопирита с пирротином или пиритом. Снижение температуры сопровождалось замещением леллингита арсенопиритом и выделением золота, сначала тонкодисперсного на границе с леллингитом, а затем более крупного. Прямая корреляция As и Au позволяет рассматривать арсенопирит как индикатор золоторудной минерализации. Au-S-As руды неоднородные, среднезернистые, вкрапленно-полосчатые, прожилковые или гнездово-вкрапленные. Количество сульфоарсенидов и сульфидов составляет 20-25 \%. Руды содержат арсенопирит (5-30 \%), леллингит (1-3 \%), пирротин (1-3 \%), халькопирит (до 5-6 \%), пирит (5-10 \%), сфалерит (1 \%), глаукодот, галенит и единичные выделения шеелита, золота, висмута и мальдонита. Рудная зона выделяется по аномальным концентрациям As, Au, иногда W (в ppm): Co 60.1-243.5; Ni 2.3-9; Cu 83-451; Zn 33.3-171.5; Sb 1.3-6.8; W 1-79; Pb до 17; Bi 0.3-3; Ag 0.07-0.14.

В Койкарской структуре золоторудное проявление Северо-Гирвасское приурочено к субмеридиональной (ССВ) шир-зоне [8]. Зона складчатой деформации и рассланцевания представлена низкотемпературными ассоциациями зеленых сланцев (хлорит, серицит, маложелезистый доломит, кварц, альбит, рутил). Нерудные минералы жил и гнезд сложены кварцем и кальцитом (в количестве 5-10\%). Рудная минерализация Северо-Гирвасского проявления представлена пиритовой вкрапленностью в тонкоплитчатых сланцах, карбонат-кварцевых гнездах и золото-стибио-арсенидносульфидной вкрапленной минерализацией в кальцит-кварцевых и кварцевых жилах и прожилках, 
секущих более ранние деформации пород. Гнездовая и жильная минерализация характеризуется следующим набором элементов: $\mathrm{S}, \mathrm{As}, \mathrm{Fe}, \mathrm{Co}, \mathrm{Ni}, \mathrm{Cu}, \mathrm{Pb}, \mathrm{Zn}, \mathrm{Sb}$, в зависимости от первичного состава измененных пород. Оруденение представлено пиритом, арсенопиритом, Fe-Ni-Co-стибиосульфоарсенидами, галенитом, Ag-Bi-галенитом, халькопиритом, сфалеритом, пенландитом, висмутом, электрумом, кюстелитом, гаухекорнитом, матильдитом, образовавшимися в мезотермальных условиях, источник вещества которых был комплексный.

Таким образом, металлогенические перспективы на золото отдельных зеленокаменных структур в обрамлении Водлозерского блока связаны с массивами гранитоидов, формировавшихся 2.86-2.85 млрд. л. и 2.74 млрд. л. назад и зонами сдвиговых деформаций в их ореоле, в меньшей степени с колчеданными рудами, которые подверглись влиянию более поздних процессов. Геохимическая специализация раннеорогенных проявлений, как в известково-щелочных гранитах, так и в шир-зонах, отличается простым набором элементов -

$\mathrm{Au}, \mathrm{Fe}, \mathrm{S}, \mathrm{As},(\mathrm{Sb})$, реже $\mathrm{Cu}, \mathrm{Zn}$, присутствием сульфидов и сульфоарсенидов сидерофильных элементов и наличием $\mathrm{Au}-\mathrm{S}$ и $\mathrm{Au}-\mathrm{S}-\mathrm{As}-$-рудно-формационных типов руд. Геохимическая специализация месторождений и рудопроявлений, завершающих формирование умереннощелочных гранитов и приуроченных к позднеархейским сдвиговым зонам носит гранитофильный профиль, характеризуется набором таких элементов, как $\mathrm{Au}, \mathrm{Bi}, \mathrm{Mo}, \mathrm{Pb}, \mathrm{Te}, \mathrm{As},(\mathrm{W}, \mathrm{Cu})$ и оруденением золоторедкометалльного рудно-формационного типа - $\mathrm{Au}-\mathrm{Mo}(\mathrm{Cu}, \mathrm{W}), \mathrm{Au}-\mathrm{Bi}-(\mathrm{Te}, \mathrm{Pb}, \mathrm{Cu}), \mathrm{Au}-\mathrm{Te}-\mathrm{Cu}$ в зональности с Au-S-As (W) минерализацией.

\section{Литература}

1. Дмитриева А.В. Металлогеническая специализация неоархейского умереннощелочного магматизма Центральной Карелии // Автореферат. 2017. 20 с.

2. Иванов Д.В, Лохов К.А. Первые данные о U-Pb возрасте цирконов из гранитного массива Талпус (Эльмусская площадь, центральная Карелия) // Матер. IV Междун. науч.-практ. конф. молодых ученых и специалистов памяти академика А.П. Карпинского. С.-Пб. 2015. С. 431-435.

3. Кулешевич Л.В. Педролампи - золото-сульфидное месторождение в докембрии Карелии // ДАН. Т. 422. № 6. 2008. С. 802-806.

4. Кулешевич Л.В., Дмитриева А.В. Аu-S-кварцевое Мо-содержащее проявление Центральное в Хаутаваарском дифференцированном массиве, Южная Карелия // Руды и металлы. № 5. 2015. С. 38-50.

5. Кулешевич Л.В., Лавров О.Б., Дмитриева А.В. Золото-сульфоарсенидная минерализация проявления Талпус, Эльмусская площадь, Карелия // Тр. ХІІ Всерос. с межд. участием Ферсмановской научной сессии, посв. 80-летию со дня рождения акад. РАН Ф.П. Митрофанова. Апатиты. 2015. С. 130-134.

6. Кулешевич Л.В., Лавров О.Б., Дмитриева А.В., Тытык В.М. Золото-содержащая полиметаллическая и сульфоарсенидная минерализация экзоконтакта Хаутаваарского массива (Южная Карелия) // Тр. КарНЦ РАН. 2017. № 11. С. 59-77.

7. Кулешевич Л.В., Тытык B.M., Компанченко A.A. Au-S-As минерализация месторождения Новые Пески в докембрии Карелии. Au-S-As минерализация месторождения Новые Пески в докембрии Карелии // Руды и металлы. 2014. №5. С. 37-45.

8. Лавров О.Б., Кулешевич Л.В. Золоторудная минерализация Койкарской структуры, Центральная Карелия // Тр. КарНЦ РАН. 2012. С. 87-99.

9. Минерально-сырьевая база республики Карелия. Под ред. Михайлова В.П., Аминова В.Н. Петрозаводск: «Карелия». 2005. Кн. 1. С. 278.

10. Олейник И.Л., Кулешевич Л.В., Лавров О.Б., Иванов Д.В. Рудно-формационные типы и минеральные ассоциации золоторудных объектов Эльмусской площади // Матер. межд. конференции «Золото Фенноскандинавского щита». Петрозаводск. 2013. С. 141-145. 